\title{
Cationic Polymerization of Para-Methyl Styrene
}

Ideisan I Abu Abdoun*

Department of Chemistry, University of Sharjah, Sharjah, United Arab Emirates

Submission: February 25, 2019; Published: March 13, 2019

*Corresponding author: Ideisan I Abu Abdoun, Department of Chemistry, University of Sharjah, Sharjah, United Arab Emirates

\section{Abstract}

Cationic polymerization of p-methyl styrene by phenacyl triphenyl phosphonium, phenacyl triphenyl arsonium and p, p`bis[(triphenylphosphonio) methyl benzophenone salts [1-3], and cation radical salt of p-substituted triphenylamine having different p-substilments was carried out photochemically and/or thermally. Cation radical amine salts were found to be more effective thermally in comparison to phosphonium or arsonium salts. The effects of initiator structure, counter ion, concentrations of salts and reaction conditions on the rate of polymerization in dichloromethane on the isolated polymer will be presented Figure 1-3.

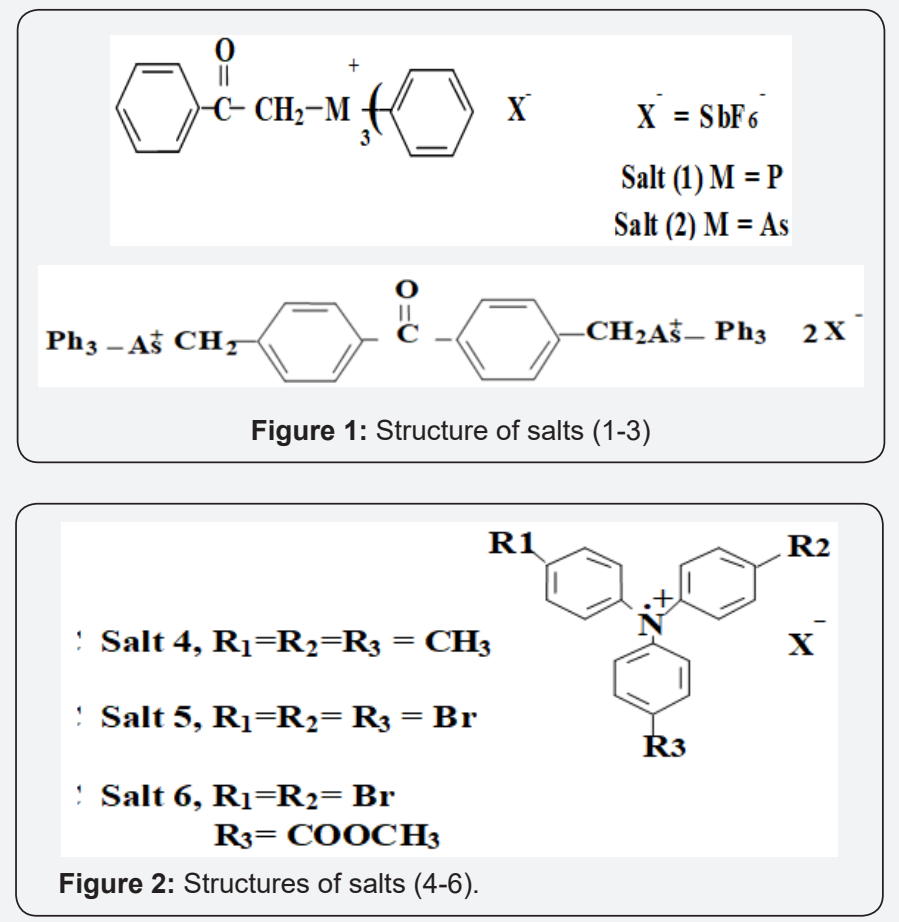

Keywords: Phenacyl triphenylphosphonium salts; Phenacyl triphenylparsonium salts; tri p-substituted triphenyl amine salts; p-methyl styrene; photo polymarization; thermal polymarization

\section{Introduction}

Poly (p-methyl styrene), PMS has excellent potential for a broad range of applications in industrial products, for example, reinforced plastic composites achieve higher thermal stability when PMS substituted for styrene [1]. The reactivity of parasubstituted styrene towards cationic polymerization depends on the type of substituent with the following order; $\mathrm{OCH}_{3}>$ $\mathrm{CH}_{3}>\mathrm{H}>\mathrm{Cl}$ have been established. Phase transfer catalyzed chlorination of poly (p-methyl styrene) occurs by the action of commercial aqueous sodium hypochlorite solution to produce the chloromethylated polystyrene, which is a key intermediate in the preparation of anion exchange resins [2], and for lithographic evaluation [3-5].

phosphonium salts such as p, p'-bis [(triphenylphosphonio] methyl] benzophenone are reported to be useful photoinitiators 
for the cationic polymerization of epoxide and vinyl monomers [6]. Recently, we reported on the use of phenacyltriphenyl phosphonium and arsonium salts as photoinitiators for the cationic polymerization of cyclohexene oxide [7], and styrene [8] and p-methylstyrene [9].

This paper will further examine the photoinitiated polymerization of p-methyl styrene by onium salts [1-3] and thermally by cation radical salts [4-6] at room temperature, and in dichloromethane.

\section{Experimental Procedures}

Onium salts preparations and characterizations were performed as reported previously [7]. The bromide salts were converted to the required photo initiator by adding 0.1 mole of each

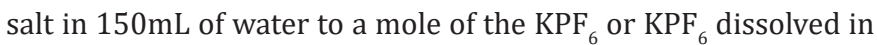
$50 \mathrm{~mL}$ of water. Para-methyl styrene, and dichloromethane (Fluka) were dried over calcium hydride and distilled prior to their use. Acetone (Fluka) "AnalaR" grade was used as received.

\section{Spectroscopic measurements}

Ultraviolet spectra were obtained on a Cary-2300 spectrophotometer. Infrared spectra were recorded on a Nicolet 50xB FT-IR spectrophotometer. NMR spectra were taken in $\mathrm{CDCl}_{3}$, on a XL200 pulsed Fourier transform NMR spectrometer with tetramethyl silane as the internal standard.

\section{Photopolymerization by onium salts (1-3)}

Photoinitiated polymerization was carried out in a $15 \mathrm{~mm}$ diameter Pyrex tube using a tight syringe for monomer addition. A homogeneous solution was formed. The reaction tubes were then closed with rubber septum, and irradiation was carried out using a merry-go-round photo reactor, Model RPR 100, obtained From the Southern New England Company. Inside the reactor's barrel was a "merry-go-round" holder, which rotate continuously by a motor, and was surrounded by sixteen Honovia 450 watt, medium pressure mercury lamps placed at a distance of $5 \mathrm{~cm}$ from the sample. The samples were placed in the holder, and were irradiated for the required period, using a light source of $350 \mathrm{~nm}$ wavelength. Poly (p-methylstyrene) was precipitated by addition of methanol, filtered, dried and weighed. From the polymer masses, the rate of polymerization was determined gravimetrically. The polymerization of p-methylstyrene by salts (1-3) is shown in Figure 4.

\section{Thermal polymerization by cation radical salts (4-6)}

Tris-p-substituted triphenylamines were fairly readily oxidized to form stable cation- radicals, and polymerization of cationically susceptible epoxide and vinyl monomers have been carried out by stable soluble, tris-(p-Bromotriphenyl) amine cation radical salts having stable counter anion such as $\operatorname{SbF}_{6}^{-}[10,11]$, which are prepared as shown in Figure 3.

Solution of the isolated salts [4-6] was found to be stable in dichloromethane, for a period of several days under laboratory conditions. The relative stability of these salt solutions in di- chloromethane and under normal laboratory conditions can be arranged as follows: salt $4>$ salt $5>$ salt 6 Figure 6 .

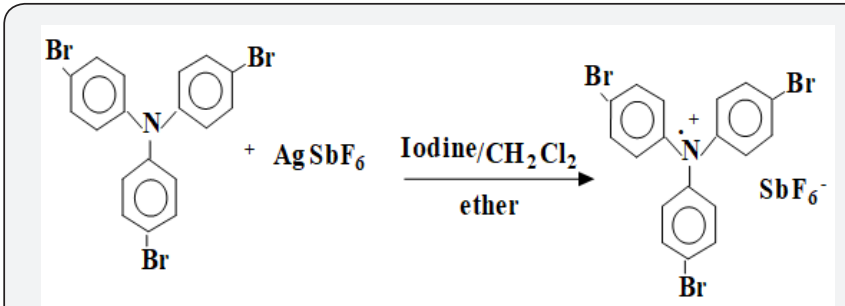

Figure 3: Synthesis of the cation radical salts

\section{Polymerization procedure}

Selected amounts of monomer and initiator solution, in dichloromethane were placed into a Pyrex tube closed with rubber septum and flushed with nitrogen. The tube was placed on a holder and left immersed for the required period in a water bath held at $25^{\circ} \mathrm{C}$. Rapid addition of initiator was achieved by syringe injection. The polymer was precipitated into methanol, filtered, dried, and weighed. Polymer yield percentage and rate of polymerization were determined gravimetrically [9]. The number averaged molecular weight $(\mathrm{Mn})$ of the isolated polymer was measured in toluene on a "Hewlett Packard" (Model 501), and High-Speed Membrane Osmometer in toluene. Molecular weight distributions were determined using a "Waters Associates" (Model 200) GPC, fitted with differential refractometer detector. The system was examined at $25^{\circ} \mathrm{C}$ in THF with a solvent flow rate of $1.0 \mathrm{~mL} / \mathrm{min}$ and a polymer concentration of $1.0 \mathrm{mg} / \mathrm{mL}$. Molecular weights were calculated with reference to polystyrene standards.

\section{Results and Discussion}

Figure 5 shows the photopolymerization of p-methylstyrene by salt [1-3] under the same experimental conditions. The monomer concentration was $2.53 \mathrm{M}$ and selected salt concentration was $3.3 \times 10^{-4} \mathrm{M}$. The rate of polymerization was increased with time and fell in the following sequence: salt $3>$ salt $2>$ salt 1 . This could be due to the termination of the growing polymer chain by the photochemically generated ylide, which suggested a transfer to initiator intermediate and possibly counter anion.



Figure 4: Polymerization of PMS by Onium salts $1,2, \& 3$.

For polymerization by onium salt (3) PMS obtained after 30 
minutes, the weight average molecular weight, MW was found to be $111,287 \mathrm{~g}$ per mole, and the number average $41,680 \mathrm{~g}$ per mol, $\mathrm{Mw} / \mathrm{Mn}=2.67$. In the case of phenacyltriphenyl phosphoniu and Arsonium salts, Bronsted acid is most likely to be the initiating species. Upon photolysis of these salts, the resonance stalilized ylide and protons are formed according to Figure 5. The suggested mechanism by which photopolymerization of p-methylstyrene initiated by the use of onium salts is given in figure below.

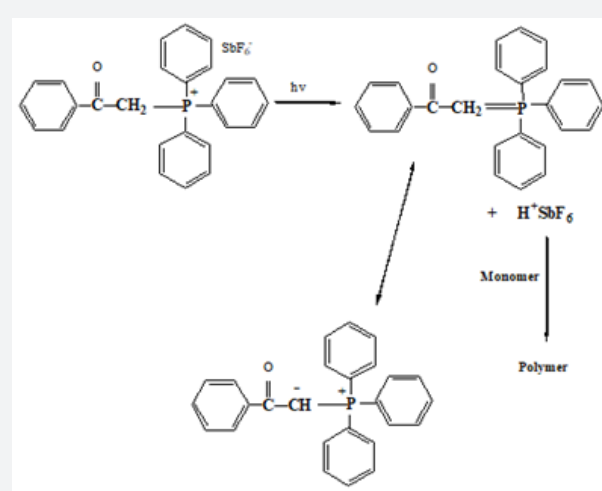

Figure 5: Photoinitiation by phenacyl triphenyl phosphonium salt.

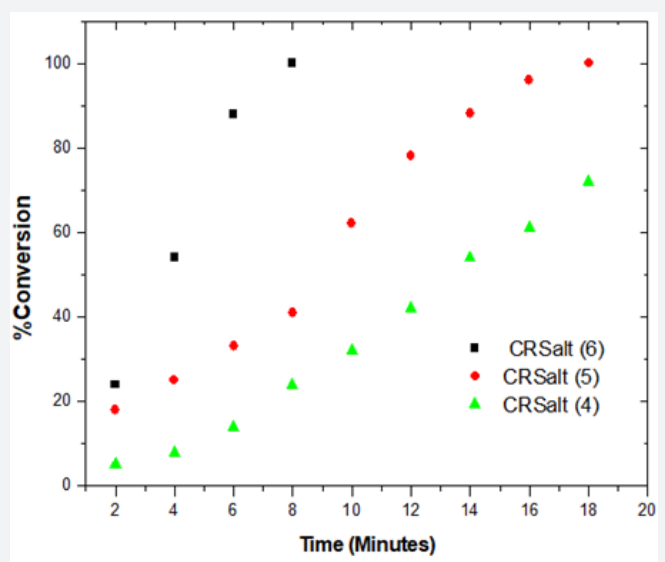

Figure 6: Polymerization of PMS by Cation Radical salts 4,5 and 6.

Figure 6 compares the efficiency of cation radical salts [4-6], under the same conditions. The reaction mixture contained $2.53 \mathrm{M}$ monomer and $3.3 \times 10^{-4} \mathrm{M}$ in dichloromethane. The results in Figure 6 show that the efficiency of cation- radical salts (4-6) fall in the following sequences: salt $6>$ salt $5>$ salt 4 . Photolysis of reaction solution containing the monomer and these cation radical salts in the concentration range reported, changed the reaction mixture color from blue to orange/red upon photolysis of salt 5 and salt 6 , and low polymerization, while solution of salt 4 showed significant increase in the amount of polymer obtained. These results suggested that photolysis of salt 5 and 6 leads to splitting of the $\mathrm{Br}$ anion, which terminated the propagated chains at the early stages of the reaction. Interaction of the cation radical salt with the monomer is the key step in the polymerization process, as polymer chains would grow following thermal initiation by both the protonic acid $\left(\mathrm{H}^{+}\right)$produced and the amine ended carbonium ion. Glass transition temperature of PMS obtained by salt (6) after 6 minutes was $381.75^{\circ} \mathrm{K}$, the weight average for the same sample was $68,766 \mathrm{~g} / \mathrm{mole}$, the number average was $27,022 \mathrm{~g} / \mathrm{mol}$, and the $\mathrm{Mw} / \mathrm{Mn}=2.54$.

\section{Conclusion}

Triphenyl phosphonium, arsonium and cation radical salts were found to be effective thermal initiators for the cationic polymerization of $\mathrm{p}$-methyl styrene. The polymerization was initiated thermally when the cation radical salts were utilized, and photochemically when phosphonium and arsonium salts were used.

\section{Acknowledgement}

Support to this work from UOS is gratefully acknowledged.

\section{References}

1. Kaeding W, Young LB, Prapas AG (1982) CHEMTECH 556.

2. Hodge P, Sherrington DC (1980) Polymer Supported Reactions in Organic Synthesis. Wiley Chichester Edn: pp. 141-200.

3. Tarascon R, Hartney M, Bowden MJ (1984) ACS symposium series 266 : 318.

4. Thompson LF, Willson CG, Frechet JMJ (1984) Materials for microlithography. Radiation Sensitive Polymers. In: Thompson LF, Willson CG, Frechet JMJ (Eds.), American Chemical Society, USA.

5. Ledwith A (1983) Chemistry of polymeric resists useful in microlithography. IEE proceedings 130(5): 245-251.

6. Neckers DC, Abu Abdoun II (1984) p, p'-Bis((triphenylphosphonio) methyl) benzophenone salts as photoinitiators of free radical and cationic polymerization. Macromolecules 17(12): 2468-2473.

7. Abu-Abdoun II, Aale Ali (1992) Cationic photopolymerization of cyclohexene oxide. Europ Polym J 28(1): 73-78.

8. Abu-Abdoun II, Aale Ali (1993) Cationic photopolymerization of styrene by phosphonium and Arsonium salts. Macromolecular Reports. A30: 327 -336.

9. Abu-Abdoun II, Aale Ali (1993) Cationic photopolymerization of p-methylstyrene initiated by phosphonium and arsonium salts. Europ Polym J 29(11): 1439-1443.

10. Abu-Abdoun II, Ledwith A (1997) Cationic polymerization photochemically and thermally induced by phenothiazine cation radical salts. Europ Polym J 33(10-12): 1671-1677. 
This work is licensed under Creative Commons Attribution 4.0 License DOI: 10.19080/AJOP.2019.02.555591

\section{Your next submission with Juniper Publishers} will reach you the below assets

- Quality Editorial service

- Swift Peer Review

- Reprints availability

- E-prints Service

- Manuscript Podcast for convenient understanding

- Global attainment for your research

- Manuscript accessibility in different formats

( Pdf, E-pub, Full Text, Audio)

- Unceasing customer service

Track the below URL for one-step submission https://juniperpublishers.com/online-submission.php 